\title{
A Study on the Material Characteristics of Stone Tools Excavated from the Remain Point of Paleolithic Age in Osong Site, Cheongju
}

\author{
Jae Hwan Kim | Min Su Han*,1 \\ Division of Conservation Science, National Research Institute of Cultural Heritage, Daejeon, 34122, Korea \\ *Department of Heritage Conservation and Restoration, Korea National University of \\ Cultural Heritage, Buyeo, 33115, Korea \\ ${ }^{1}$ Corresponding Author: dormer@nuch.ac.kr, +82-41-830-7381
}

\begin{abstract}
This study analyzes the material characteristics of stone tools of the Paleolithic period excavated from the Osong site, located at the project site for the creation of the Osong 2nd Life Science Complex, and estimates the provenance of the stone materials. Because the stones had been buried for a long time, their surfaces had become heavily weathered yellow or yellowish-brown, and the magnetic susceptibility values varied from 0 to $15\left(\times 10^{-3} \mathrm{SI}\right)$. The excavated stone tools were rocks with various magnetic susceptibility values that could not be specified. Five stone tools subjected to destructive analysis were divided into two groups, one with a value of $1-3\left(\times 10^{-3} \mathrm{SI}\right)$ and the other with a value of $5-9\left(\times 10^{-3}\right.$ SI), both based on visible characteristics. The results of the thin-section analysis showed that most of the stone tools were basaltic rocks comprising plagioclase, quartz, and pyroxene, and some had iron content as high as $20 \mathrm{wt} . \%$. These findings and the present geological map suggest that the stone tools were not made from the surrounding rocks because there are no areas containing basaltic rocks surrounding Bongsan-ri in Osong-eup. Andesite and tuff are distributed along with basaltic rocks in the Doan-myeon area in Jeongpyeong-gun, Chungcheongbuk-do Province, but the distance from the excavation site is too far. To determine whether this region is actually related to the provenance of the raw rock, it is necessary to conduct additional field surveys and comprehensive and precise analyses.
\end{abstract}

Key Words: Stone tools, Osong site, Paleolithic age, Basaltic rock, Provenance

\section{INTRODUCTION}

Stone tools are made by processing rocks and used as tools for various purposes. It has been reported that they are classified into hunting and fishing tools, food production tools, wood-making tools, harvesting tools and hand tools, though there are differences among the researchers in the type classification(Yoon, 2015).

Research on stone tools in Korea has been widely carried out from prehistoric times to the paleolithic, neolithic and bronze age. And, the formal classification based on the type of stone tools have become mainstream(Park, 1983; Lee, 2000; Lee, 2001). In particular, the researches of these stone tools are a very important part in the study for neolithic age based on the style of earthenware, because it is able to look at the life of the neolithic people who used stone tools and get off an existing point in the style of earthenware, the part that started the research with interest is the technical aspect of the manufacturing method and the production process of the stoneware(Clark and Kleindienst, 1974). After that, researches on the raw materials and the production process such as quartzite stone artifact and obsidian stoneware have been recently conducted in Korea(Lee, 2010; Min, 2013; Jeong, 2017). In addition, in the natural sciences, studies on the lithological properties of stone tools and the estimation of the source of raw rocks have been attempted, and research has been undertaken to determine which raw rocks have been used and processed depending on the type and application of the stone tools(Park et al., 2007; Lee et al., 2014; Kim et al., 2015). In other words, these studies have 
examined the relationship between different types of stone tools in various forms and applications, such as blade tools, chipped stone, flake etc. In addition, by comparing the characteristics of the rock types used in the production of these stone tools, we can see how old people actually selected stone to be processed to make stone tools, it will be for

The stone tools excavated from the paleolithic site of the Osong area, which is the study area, are important in terms of comparative study with stone tool excavated from various site such as Mansuri site and Ryuldong dynasty site. It is regarded as very important for revealing the life of the central region in the paleolithic age, together with stone tools excavated from the remains of the Seokjangri, Kongju.

Until now, this area, 'The Osong Second Life Science Complex', is located around Bongsan-ri, Osong-eup, Cheongju-city, Chungcheongbuk-do. In the site, the cultural layers of the paleolithic age, the settlements of the bronze age, the tombs of the Three Kingdoms period, and the houses and settlements of the Joseon Dynasty were identified. And the sites excavated with stone tools are classified into three points(Jungang Institute of Cultural Heritage and Chungbuk Development Corporation, 2018a). The distance between each point is as follows. No. 2 point is located $200 \mathrm{~m}$ to the west from No.1 point, and No.3 point is located 200 to $300 \mathrm{~m}$ to the north from No.1 point (Jungang Institute of Cultural Heritage and Chungbuk Development Corporation, 2018b). First, the No.1 point which is around 144, Bongsan-ri, Osong-eupa was single cultural layer of the paleolithic age and 2449 stone tools were collected (Jungang Institute of Cultural Heritage and Chungbuk Development Corporation, 2018a).

The No.1 point of the paleolithic age is located at 206, 262 and 263, Bongsan-ri, Osong-eup and a total of 1,469 stone tools were collected form the remains layer of the paleolithic(Central Institute of Cultural Heritage and Chungbuk Development Corporation, 2018a). A total of 1527 stone tools were identified at No.3 point, similar to the No.2 point, with remains layer of the paleolithic age(Central Institute of Cultural Heritage and Chungbuk Development Corporation, 2018b).

In this study, eleven stone tools were selected from two points of the paleolithic age excavated from the site of the Osong Second Life Science Complex. And physical properties such as color and appearance characteristics and precursor potential were examined. Among them, five stone tool samples capable of destructive analysis were analyzed by thin-section analysis and mineral composition analysis. Finally, the origin of the raw rocks used in the production of stoneware was estimated by reviewing the geological characteristics data around the ruin. The results of this study are expected to be used as an important data for the material study of stone tools excavated from the remains of the Paleolithic period in the middle area.

\section{METHODS}

First, precise visual observation were carried out 11 stone tools in order to check the current conditions of them for the influence of the buried environment, and their magnetic susceptibility values were measured to analyze the magnetization intensity. Magnetic susceptibility was measured using the Magnetic Susceptibility Meter(SM-20, GF Instruments, Czech), which measures up to $10^{-5} \mathrm{SI}$ units, and after 10 measurements, the values of stone tools were expressed in $10^{-5} \mathrm{SI}$ unit. In addition, X-ray fluorescence analysis(Vanta C series, Olympus, USA) was carried out to determine the possibility of iron ore for 1 sample with a high specific gravity. For the five stone tools capable of destructive analysis, the contaminants attached to the surface were washed with flowing water, then the surface layer was partially removed using a diamond tip, and then rinsed with distilled water. After that, they were put into a dryer oven and completely dried at a temperature of $100 \pm 5^{\circ} \mathrm{C}$ to prepare a samples. Crystallographic phase analysis was carried out using X-ray diffractometer(D8 Advance, Bruker, USA), and the diffractograms were analyzed using High Score Plus software and ICSD database. The measurement conditions were $40 \mathrm{kV}, 40 \mathrm{~mA}$, $5^{\circ} \sim 70^{\circ}$, and $0.019^{\circ} / 31.6 \mathrm{sec}$, and the anode material used was $\mathrm{Cu}$, the divergence slit size was $0.6 \mathrm{~mm}$, and the receiving slit size was $0.1 \mathrm{~mm}$. In addition, thin-section analysis was carried out using polarizing microscopy $(\mathrm{Bx}-$ 
40, Olympus, Japan) to detect mineral composition by semiquantitative method, symbiotic relationships, microstructures, and the formation of altered minerals by weathering.

The results of these analyzes were interpreted synthetically to understand the petrological characteristics and homogeneity, and the origin of the raw rocks, which were presumed to have been used to make the stone tools, was examined, because it was not possible to perform accurate geological survey around the actual ruin, it was estimated by using the geological map of the ruin and surrounding area.

\section{STATUS AND MATERIALS}

\subsection{Geographical features and geology}

The site of Osong are located at the western end of Heungduk-gu, Cheongju-city, Chungbuk, which is the midwestern part of the Korean peninsula and it is adjacent to Sejong-eup, Sejong Special Self-governing City. In the east, it is adjacent to Oksan-myeon and KangNae-myeon with the boundary of Miho stream. The latitude corresponds to latitude $36^{\circ} 36^{\prime} \sim 36^{\circ} 38^{\prime}$ and longitude $127^{\circ} 18^{\prime} \sim 127^{\circ} 20^{\prime}$ (Jungang Institute of Cultural Heritage and Chungbuk Development Corporation, 2018a).

The geology of this area is roughly divided into granitic rocks which are mostly intruded by Jurassic period, partly gneiss and schist, and the alluvium layer is covered. Porphyry granite is distributed in the western part, and intrudes banded biotite granite, Its composition minerals are quartz, orthoclase, plagioclase, biotite, and hornblende, and the orthoclase appears in th form of hypocrystalline texture. Biotite granites are distributed in the eastern part and has homoeobastic texture. Their composition minerals are quartz, plagioclase, biotite, muscovite and hornblende, and

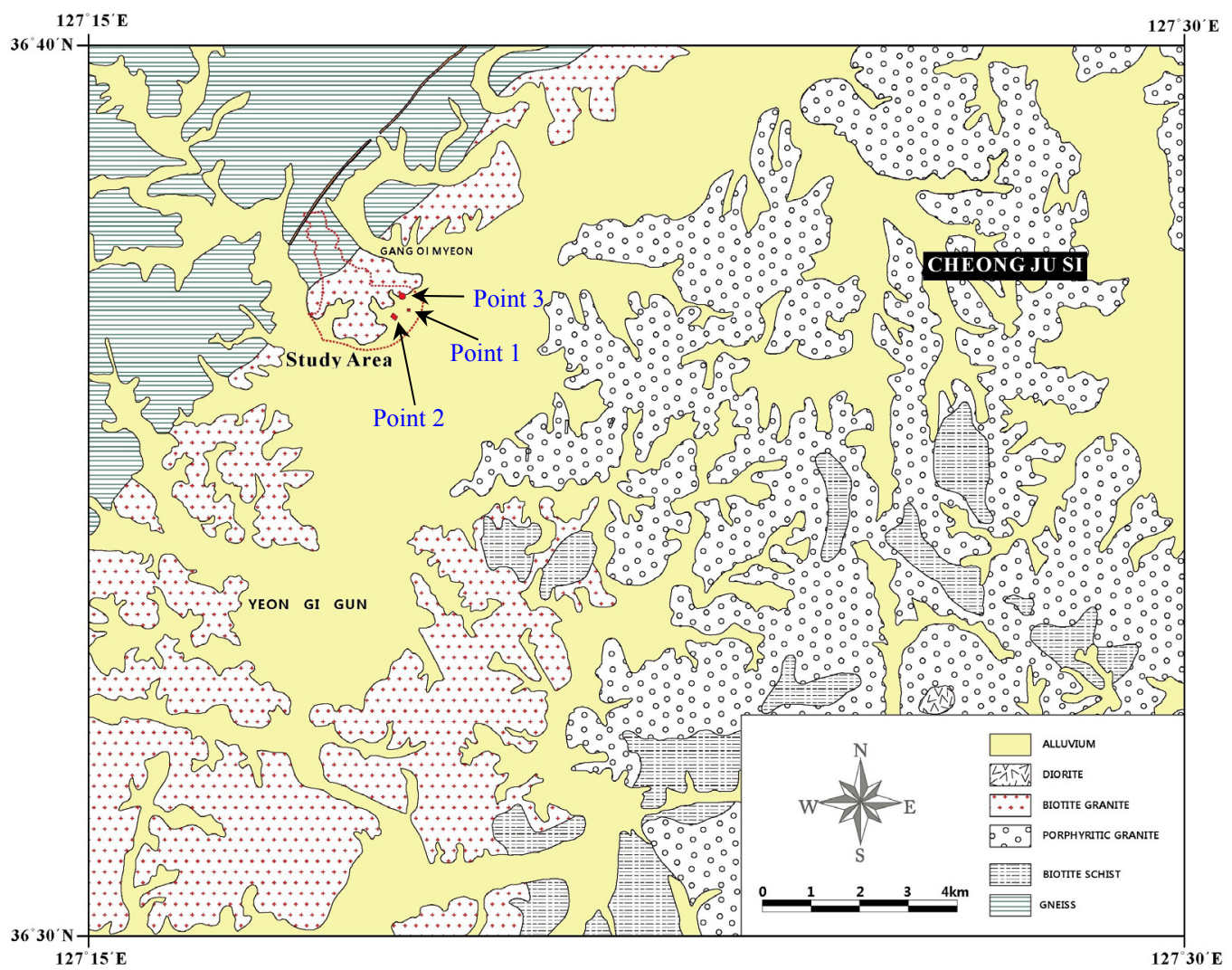

Figure 1. Geological map around the Osong site(Modified after Gwon and Jin, 1974). 
some biotite granites contain garnet(Gwon and Jin, 1974).

The geological features of remains in the Paleolithic age is located in the biotite granite area, which are mainly distributed in the northwest, and is located in the biotite granite area, which is distributed in the northeast-southwest direction of the porphyritic granite zone located in the southeast(Figure 1).

\subsection{Materials}

As a result of the analysis for used mark of the 5445 stone tools excavated from three sites of the paleolithic age in Osong ruin, most of the stone tools were similar in conditions, types of them and the kinds of raw rock, and they were judged to be quartz rocks or quartzites, and the

Table 1. Analytical stone tools excavated from remains layer of paleolithic age in Osong site

\begin{tabular}{|c|c|c|c|c|}
\hline $\begin{array}{l}\text { Sample } \\
\text { code No. }\end{array}$ & Excavation point & Name of stone tool & Quantity & Remarks \\
\hline 2416 & \multirow{8}{*}{ No.1 site of the paleolithic age } & Core & $1 \mathrm{EA}$ & Destructive analysis \\
\hline 2417 & & Biface & 1EA & " \\
\hline 2418 & & Hand-plane & 1EA & None-destructive analysis \\
\hline 2419 & & Other stone & 1EA & " \\
\hline 2420 & & Other stone & $1 \mathrm{EA}$ & " \\
\hline 2421 & & Hand-axe & $1 \mathrm{EA}$ & " \\
\hline 2422 & & Other stone & $1 \mathrm{EA}$ & Destructive analysis \\
\hline 2423 & & Other stone & $1 \mathrm{EA}$ & " \\
\hline 1498 & \multirow{3}{*}{ No.3 site of the paleolithic age } & Core & $1 \mathrm{EA}$ & None-destructive analysis \\
\hline 1499 & & Hand-axe & $1 \mathrm{EA}$ & Destructive analysis \\
\hline 1527 & & Biface & $1 \mathrm{EA}$ & None-destructive analysis \\
\hline 2416 & 2417 & 2418 & & 2419 \\
\hline 2420 & 2421 & 2422 & & 2423 \\
\hline 1498 & 149 & & & \\
\hline
\end{tabular}

Figure 2. External characteristics of stone tools excavated from remains layer of paleolithic age in Osong site. 
raw rocks were probably collected from the Miho stream water system around the site(Kim, 2018). Therefore, in this study, the analysis of the material characteristics of stone tools was performed only on them which are estimated to be relatively unusual rocks and those that are somewhat impossible to judge externally. First, a total of 11 samples were selected at No.1 point and No.3 point, and five samples were carried out destructive analysis. The states of the analytical samples are shown in Figure 2, and the list of excavated artifacts is shown in Table 1.

\section{RESULTS}

\subsection{Analysis of magnetic susceptibility}

The magnetic susceptibility is an index indicating the degree to which a material can be magnetized, and is a ratio of intensity of magnetization to force of magnetic field, and has a dimensionless value. It can be easily measured outdoors for rock samples that are difficult to judge with the macroscopy, and it is useful for determining the homogeneity of rocks with the resultant values. Therefore, the stone tools excavated from the remain point of paleolithic age in Osong site were measured 10 times for each sample using a magnetic susceptibility meter, and then the frequency was calculated according to the measured values and compared.

As a result of examining the measured magnetic susceptibility

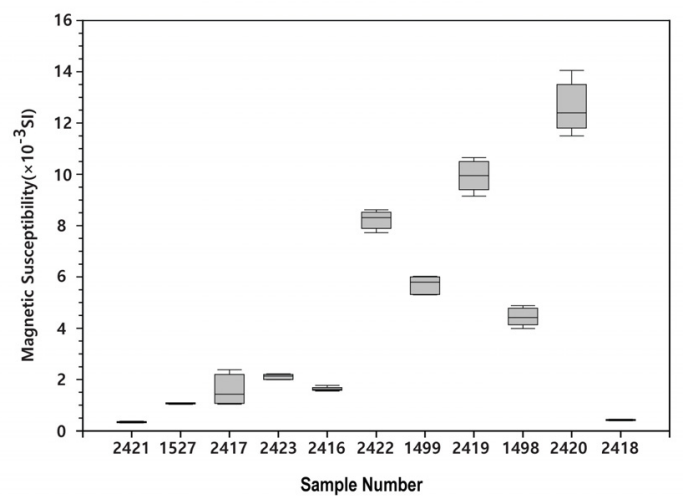

Figure 3. Magnetic susceptibility values of 11 stone tools excavated from remains layer of paleolithic age in Osong site. values for 11 stone tools in all, it showed wide distribution characteristics from 0 to $15\left(\times 10^{-3} \mathrm{SI}\right)$ (Figure 3 ). In addition, the magnetic susceptibility values of the five stone tools, which are destructive analysis samples, sample cord number 2416 is $1.62 \sim 1.85\left(\times 10^{-3} \mathrm{SI}\right), 2423$ is $1.99 \sim 2.24\left(\times 10^{-3} \mathrm{SI}\right), 2422$ is $7.67 \sim 8.68\left(\times 10^{-3} \mathrm{SI}\right), 1499$ is $5.29 \sim 6.04\left(\times 10^{-3} \mathrm{SI}\right)$, and 2417 is the value of $1.03 \sim 2.41\left(\times 10^{-3} \mathrm{SI}\right)$. By classifying these stone tools as a magnetic susceptibility values, the stone tools are classified into two groups based on magnetic susceptibility values. One group is 2416, 2417, and 2423 samples with values between 1 and 3, other groups are 1499 and 2422 samples with values between 5 and 9(Figure 4).

\subsection{Observation of polarizing microscope}

To determine the homogeneity of the stone tools, a thin section was made on the small specimen obtained from the main body, and then the minerals composition of the stone tools and the presence of altered minerals that could be formed by the weathering and texture were observed using a polarizing microscope.

As a observation of polarizing microscope revealed that the stone tools excavated from remains layer of paleolithic age in Osong site have similar basaltic rock characteristics. That is, most of the major composition minerals of stone tools were identified as plagioclase, quartz, and pyroxene (Figure 5). Microtextures are microcrystalline which composed

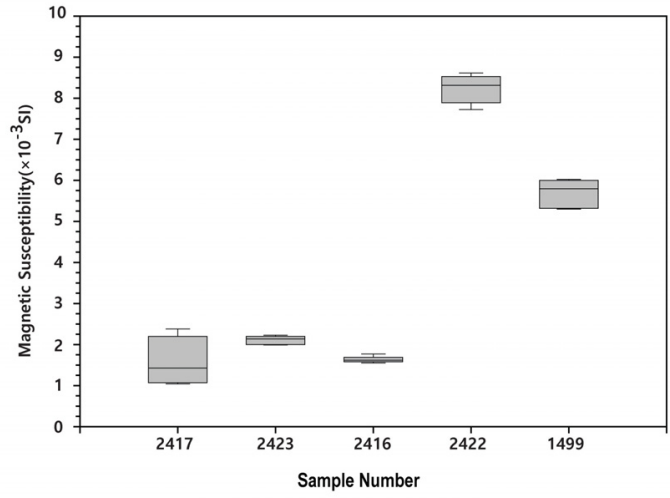

Figure 4. Magnetic susceptibility values of five stone tools excavated from remains layer of paleolithic age in Osong site. 

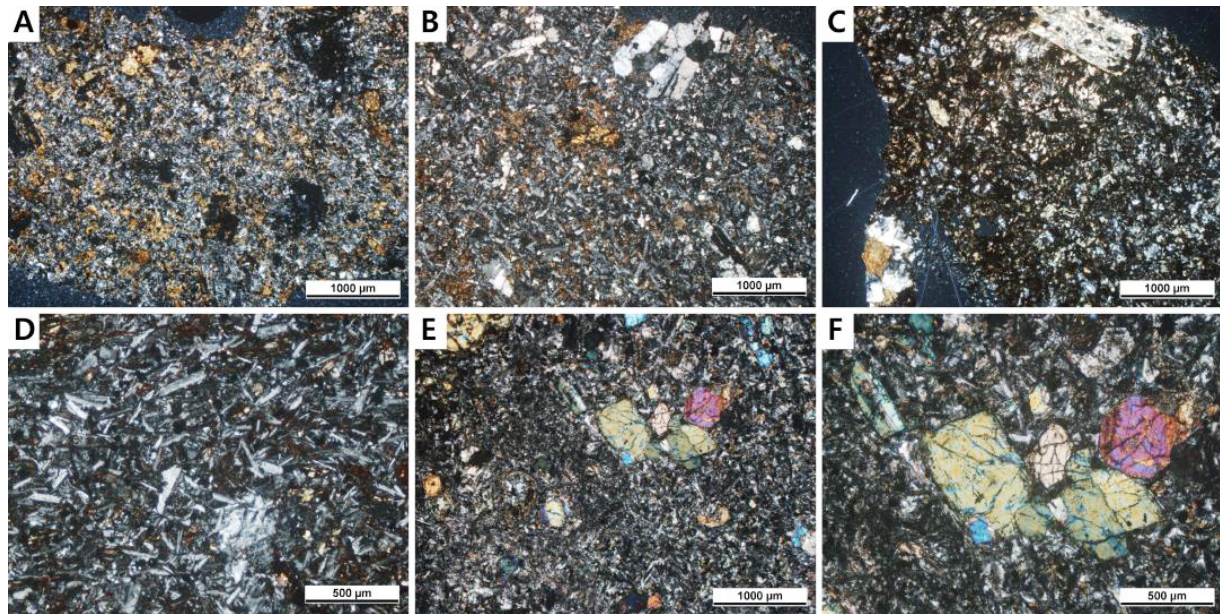

Figure 5. Images of thin section for 5 stone tools excavated from remains layer of paleolithic age in Osong site. (A) 2417, (B) 2423, (C) 2416, (D) 2422, (E, F) 1499. Sample numbers are the same as those of Table 1.

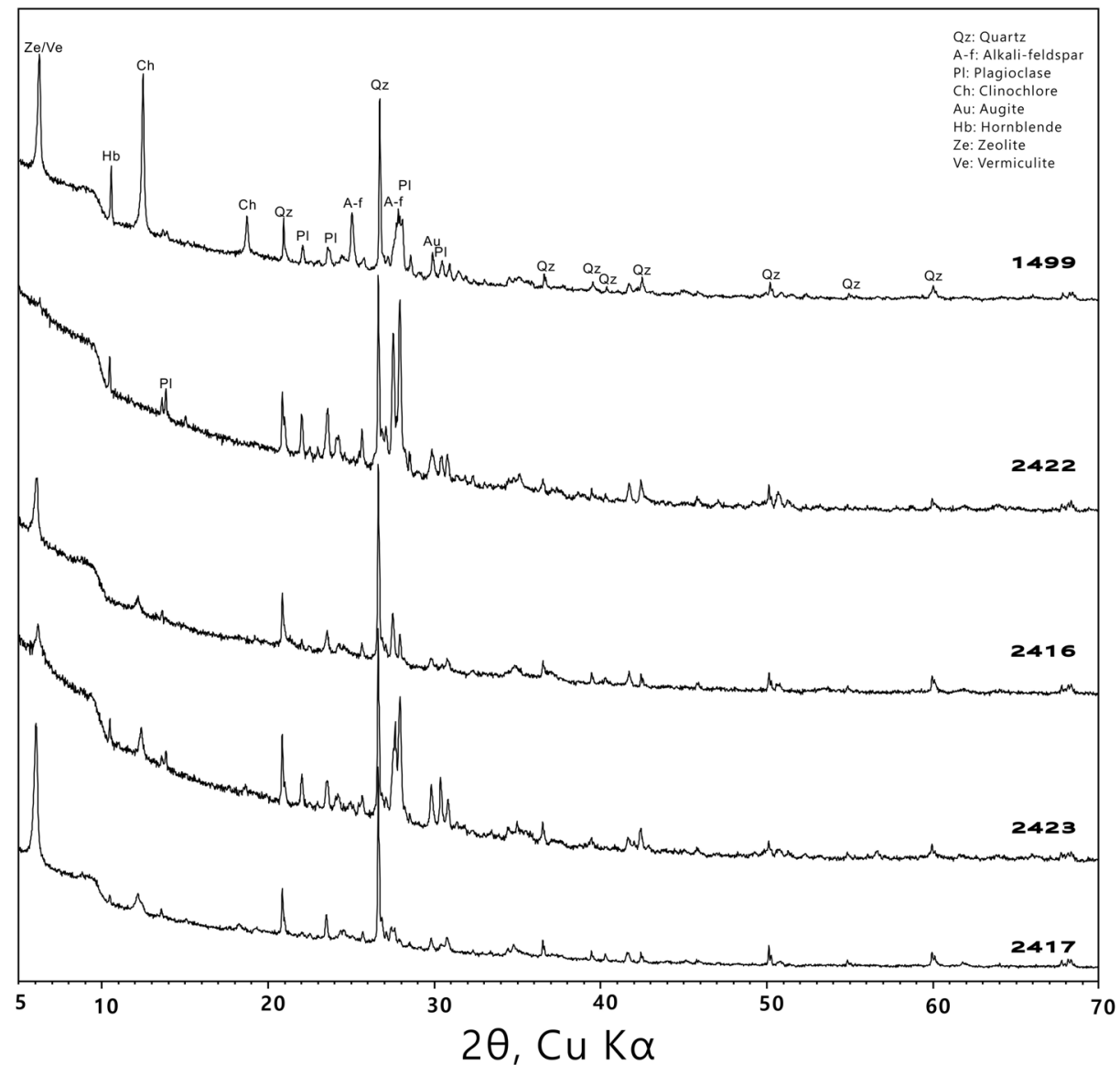

Figure 6. Results of X-ray diffraction patterns for 5 stone tools excavated from remains layer of paleolithic age in Osong site. 
of very small grains in all specimens, but 2417, 2423 and 2416 have relatively finer grain characteristics than 2422 and 1499. In addition, 2417, 2423, and 2416 indicate that a large amount of clayed material is partially mixed by weathering. 2422 is mostly identified with an albite twin, and is partially identified as a Carlsbad twin. 1499 is characterized by augite and differs from other samples.

\subsection{Composition analysis of minerals}

X-ray diffraction analysis is a useful analytical method for determining the mineral composition of sedimentary rocks or fine grains that are difficult to mined under a microscope, and in the case of highly deterioration rocks.

As a result of X-ray diffraction analysis to reveal the composition minerals of stone tools excavated from remains layer of paleolithic age in Osong site more precisely, their X-ray diffraction patterns were mostly similar. That is, the composition minerals of the stone tools were quartz and alkali feldspar, plagioclase, vermiculite, chlorite and pyroxene. However, the relative strength of the composition minerals were different according to the samples(Figure 6). Except for the specimen of 2422, vermiculite and clinochlore were identified in other specimens. These minerals are mainly minerals produced by alteration of minerals such as mica, and it can be inferred that the stone tools were weathered in the buried environment in ground. Also, it can be seen that the clayed yellow particles in the analysis of thin section are clay minerals such as vermiculite, and the results of the XRD analysis are consistent with those of the thin section.

\section{Discussion}

Mineralogical features and provenance of the five stone tools which were analyzedby the destructive method were discussed more deeply and comprehensively in this paper.

First, mineralogical features are similar to the composition of minerals as shown in Table 2.

The microtexture contains microparticulate materix and plagioclase showing euhedral or anhedral crystal, and it can be confirmed that the feldspar in the interior is altered by weathering.

In addition, the mineralogical features was divided into the typical Basalt group(sample code No.2422 and No.1499) and the basalt group(sample code No.2416, No.2417 and No.2423). These results are the same as the results of magnetic susceptiblility analysis.

As a result of the above, except for the quartz stone tools, which occupy most of the stone tools excavated from

Table 2. Results of mineralogical analysis for stone tools of paleolithic age in Osong site

\begin{tabular}{|c|c|c|c|}
\hline $\begin{array}{l}\text { Sample } \\
\text { code No. }\end{array}$ & Minerals & Microtexture & Rock type \\
\hline 2416 & $\begin{array}{l}\text { Quartz, Plagioclase, } \\
\text { Alkali-feldspar, } \\
\text { Clinoc hlore, Clay mineral }\end{array}$ & $\begin{array}{l}\text { Microparticulate materix, Plagioclase phenocryst of } \\
\text { anhedral crystal, Plagioclase shows Albite-Carlsbad } \\
\text { twin, Most of the minerals are weathered }\end{array}$ & $\begin{array}{l}\text { Basalt } \\
\text { (altered) }\end{array}$ \\
\hline 2417 & $\begin{array}{l}\text { Quartz, Alkali-feldspar, } \\
\text { Clinochlore, Clay mineral }\end{array}$ & $\begin{array}{l}\text { Microparticulate materix, Plagioclase phenocryst of } \\
\text { anhedral crystal, Plagioclase shows Albite-Carlsbad } \\
\text { twin, Most of the minerals are weathered }\end{array}$ & $\begin{array}{l}\text { Basalt } \\
\text { (altered) }\end{array}$ \\
\hline 2422 & $\begin{array}{c}\text { Quartz, Plagioclase, } \\
\text { Alkali-feldspar, Hornblende }\end{array}$ & $\begin{array}{l}\text { Microparticulate materix, Plagioclase phenocryst of } \\
\text { enhedral crystal, Plagioclase shows Albite-Carlsbad twin }\end{array}$ & Basalt \\
\hline 2423 & $\begin{array}{l}\text { Quartz, Plagioclase, } \\
\text { Alkali-feldspar, Clinochlore, } \\
\text { Hornblende, Clay mineral }\end{array}$ & $\begin{array}{c}\text { Microparticulate materix, Plagioclase phenocryst of } \\
\text { enhedral crystal, Plagioclase shows Albite-Carlsbad } \\
\text { twin, Feldspar was altered by weathering }\end{array}$ & $\begin{array}{c}\text { Basalt } \\
\text { (altered) }\end{array}$ \\
\hline 1499 & $\begin{array}{l}\text { Quartz, Plagioclase, } \\
\text { Alkali-feldspar, } \\
\text { Clinochlore, Hornblende, } \\
\text { Augite, Clay mineral }\end{array}$ & $\begin{array}{l}\text { Microparticulate materix, Plagioclase and augite } \\
\text { phenocryst of enhedral crystal, Plagioclase shows } \\
\text { Albite-Carlsbad twin, Feldspar was altered by weathering }\end{array}$ & Basalt \\
\hline
\end{tabular}


Osong site, the small and unique five stone tools are not iron ore like magnetite(In general, the amount of the iron in excess of $60 \%$ is referred to as the 'Rich ore', and the amount of less than $40 \%$ is called the 'Poor ore'). That is to say, they are basaltic rocks with more or less iron content. Of course, some stone tool(No.2419) that show an iron content of around $20 \mathrm{wt} . \%$ in the nondestructive analysis, but this is a very low grade ore to name a common iron ore(low-grade ores with a low iron content of about $25 \%$ are also used for steelmaking in recent years).

Considering these results, there is one question, which is the origin of basaltic rocks. The geologic map reported so far does not have a large area of basaltic rocks around Bongsan-ri in Osong-eup, the nearest geographical distribution is in Doon-myeon, Jeungpyeong-gun province, where basaltic rocks are narrowly distributed along with andesite and tuff.

However, since the area is relatively far from the ruins(about $35 \mathrm{~km}$ ), further research is needed to see whether it is actually related to the origin, and it is clear that the type of stone tools excavated from the site of paleolithic age is a rock that can not be easily found in the surrounding area, and the use and meaning of the stone tools are considered to be more advanced and scientific.

\section{CONCLUSIONS}

The eleven stone tools of the paleolithic period excavated from creation site of 'The Osong Second Life Science Complex' analyzed for magnetic susceptibility measurement, thin section and mineral composition, and comparing these results, we can see the correlation between stone tools and the types of rocks used in making stone tools. And the following conclusions were obtained.

First, most of the stone tools were light yellow to yellowish brown, and black color was observed in cracks and some missing parts. Also, since they were buried in the ground for a long time, a large amount of soil particles adhered to the surface, and the weathering was proceeding severely and the weathering layer was peeling off.

Second, magnetic susceptibility values are widely distributed from 0 to $15\left(\times 10^{-3} \mathrm{SI}\right)$ in 11 stone tools. These values show that the stone tools excavated are various stones that can not be specified. But distinctively, the five stone tools that are carried out to the destructive analysis are divided into two different groups.

Third, thin sections were observed with a polarizing microscope, and the stone tools were basaltic rocks composed of plagioclase, quartz, and pyroxene.

Fourth, XRD analysis showed that the stone tools consisted of quartz, plagioclase, alkali feldspar, mica, vermiculite, chlorite and pyroxene. Their diffraction patterns were similar to each other, and the difference in relative diffraction intensity and the composition minerals of them was estimated to be due to weathering grade.

As a result of the above results, except for the quartz stone tools, which occupy most of the stone tools excavated from Osong site, the small and unique 5 stone tools which were analyzed in this paper by the destructive method are not iron ore like magnetite. That is to say, they are basaltic rocks with more or less iron content. Of course, some stone tool(No.2419) that show an iron content of around 20 wt.\% in the nondestructive analysis, but this is a very low grade ore to name a common iron ore.

Considering these results, there is one question, which is the origin of basaltic rocks. The geologic map reported so far does not have a large area of basaltic rocks around Bongsan-ri in Osong-eup, the nearest geographical distribution is in Doon-myeon, Jeungpyeong-gun province, where basaltic rocks are narrowly distributed along with andesite and tuff. However, since the area is relatively far from the ruins(about $35 \mathrm{~km}$ ), further research is needed to see whether it is actually related to the origin. However, it is clear that the type of stone tools excavated from the site of paleolithic age is a rock that can not be easily found in the surrounding area, and the use and meaning of the stone tools are considered to be more advanced and scientific.

In conclusion, all of the stone tools analyzed in this study were basaltic rocks, and scientific analysis of them revealed various and distinctive types of rock, so that we can identify the origin of artifacts excavated from the same relics. Furthermore, it is a good way to judge the correlation 
with the stone tools excavated from the sites of paleolithic ages of the similar areas. In addition, if such a study is continuously carried out, it is expected that this study will be useful to the identification of the culture for paleolithic period of the korea central area in the future.

\section{ACKNOWLEDGEMENT}

This paper was carried out as part of the natural science analysis project of the stone tools and I am grateful to the Jungang Institute of Cultural Heritage who provided the samples.

\section{REFERENCES}

Clark, J.D. and Kleindienst, M.R., 1974, The Stone Age cultural sequence : terminology, typology and raw material. Kalambo Falls Prehistoric Site.

Gwon, Y.I. and Jin, M.S., 1974, Explanatory text of the geological map of Cheongju sheet $(1: 50,000)$. National Institute of Geoscience and Mineral, 2-5. (in Korean with English)

Jeong, C., 2017, A study of obsidian stone tool in Neolithic Period of Korean Peninsula. Master's thesis, Pusan National University, Busan. (in Korean with English abstract)

Jungang Institute of Cultural Heritage and Chungbuk Development Corporation, 2018a, 'The Osong Second Life Science Complex' development project site - Paleolithic 1.2 points -. Report of Cultural Heritage Site, 7-240. (in Korean) Jungang Institute of Cultural Heritage and Chungbuk Development Corporation, 2018b, 'The Osong Second Life Science Complex' development project site-Paleolithic 3 points -. Report of Cultural Heritage Site, 7. (in Korean)

Kim, K.J., 2018, Analysis for the used marks of stone tools excavated at No. $1 \cdot 2 \cdot 3$ points of the Paleolithic age in Osong site. 'The Osong Second Life Science Complex' development project site - Paleolithic 3 point -. Jungang
Institute of Cultural Heritage and Chungbuk Development Corporation, 338-339. (in Korean)

Kim, S.W., Hwang, G.H., Moon, S.W. and Jwa, Y.J., 2015, Petrological characteristics and provenance estimation on the stone artifacts from the Pocheon Neulgeori Prehistoric site, Korea. The Journal of the Petrological Society of Korea, 24, 1-10. (in Korean with English abstract)

Lee, H.W., 2001, Research and quantitative analysis of artifact properties. Journal of the Korean Palaeolithic Society, 3, 71-84. (in Korean with English abstract)

Lee, J.K., 2000, Symbol system for evaluation of stone tools combinations. Journal of the Korean Palaeolithic Society, 2, 33-40. (in Korean with English abstract)

Lee, I.H., 2010, The study of the production process of stone tools in the settlement for Bronze Age. Master's thesis, Korea University, Seoul. (in Korean with English abstract)

Lee, C.H., Kim, R.H. and Eo, E.I., 2014, Interdisciplinary study on Bronze Age artifacts in Midwestern Korea : material characteristics and provenance presumption for stone artifacts of the Sinsongri site in Seosan. Journal of Conservation Science, 32, 2, 205-217. (in Korean with English abstract)

Min, K.I., 2013, Vein quartz and quartzite retouched stone artifacts from the Gyeonggi area, Korea. Master's thesis, Kyung Hee University, Seoul. (in Korean with English abstract)

Park, S.M., Lee, C.H., Kim, J.Y. and Jung, I., 2007, Material characteristics and provenance presumption for stone artifacts of Bronze Age from the Hyocheon site in Gwangju, Korea. Journal of Conservation Science, 21, 5-20. (in Korean with English abstract)

Park, Y.C., 1983, About the classification of chipped stone tools in the Paleolithic Age I. The Journal of Humanities, 8, 69-85. (in Korean with English abstract)

Yoon, J.G., 2015, A study on stone tools of production in Neolithic Korea. Doctoral dissertation, Chonnam National University, 67. (in Korean with English abstract) 